Sains Malaysiana 48(12)(2019): 2633-2640

http://dx.doi.org/10.17576/jsm-2019-4812-04

\title{
Preliminary Characterization of Exopolysaccharides Produced by Abortiporus biennis in Submerged Fermentation
}

(Pencirian Awal Eksopolisakarida yang Dihasilkan oleh Abortiporus biennis dalam Fermentasi Tenggelam)

\author{
Zhangde Long, Hong LiU, JigAng Li, JiAnsheng Sun, Yun Xue, Zhizhong Hu, Zan Su,
} CHUNPING XU \& JING-KUN YAN*

\begin{abstract}
Abortiporus biennis is a rare edible and medicinal mushroom that is valuable in traditional Chinese medicine. Exopolysaccharides (EPSS) as valuable metabolites have been harvested from fermentation broths of A. biennis. However, studies on preliminary characterisations and bioactivities of A. biennis EPSs are lacking. In this study, therefore, the production, characteristics and bioactivity of EPSs produced by A. biennis in submerged fermentation were investigated. An EPS-1 was isolated and purified from the culture broth of A. biennis using a Sepharose CL-6B column chromatography. The molecular weight, monosaccharide composition, structural characteristics, chain conformation and thermal property of EPS-1 were determined by gel-filtration chromatography, gas chromatography-mass spectroscopy, Fourier-transform infrared spectroscopy, Congo red test and thermogravimetric analysis, respectively. The in vitro antioxidant and immunoregulation activities of the EPS- 1 were evaluated by adopting DPPH and hydroxyl radical-scavenging assays, and analysing NO production in macrophage RAW 264.7 cells, respectively. Results showed that the culture medium containing $30 \mathrm{~g} / \mathrm{L}$ lactose and $3.0 \mathrm{~g} / \mathrm{L}$ tryptone had the most suitable carbon and nitrogen sources, respectively, for EPS production in A. biennis. The maximum EPS production $(18.29 \mathrm{~g} / \mathrm{L})$ was obtained after 6 days of cultivation in a 5 L stirred-tank reactor under the most suitable culture medium. After purification, EPS-1 with $85.4 \%$ yield and $96.1 \%$ carbohydrate content was obtained from the culture broth of A. biennis. EPS-1 was characterised as a neutral heteropolysaccharide with a molecular weight of $22.07 \mathrm{kDa}$ and is composed of glucose, mannose and galactose at a molar ratio of 3.3:2.0:1.0. EPS-1 with a relatively high thermal stability existed as a random coil conformation in the aqueous medium and possessed prominent radical-scavenging ability and macrophage stimulation activity in vitro. Therefore, EPS-1 could be explored as a functional ingredient with potential applications in food, medical and cosmetic industries.
\end{abstract}

Keywords: Abortiporus biennis; bioactivity; exopolysaccharides; preliminary characterisation; submerged fermentation

ABSTRAK

Abortiporus biennis adalah cendawan yang boleh dimakan dan boleh digunakan dalam ubatan yang sangat berharga dalam perubatan tradisi Cina. Eksopolisakarida (EPS) sebagai metabolit berharga telah dituai daripada kaldu fermentasi A. biennis. Walau bagaimanapun, kajian mengenai pencirian awal dan bioaktiviti A. biennis EPS adalah agak kurang. Oleh itu, dalam kajian ini, pengeluaran, ciri-ciri dan bioaktiviti EPS yang dihasilkan oleh A. biennis dalam fermentasi tenggelam telah dilakukan. EPS-1 telah dipencilkan dan ditulenkan daripada kultur kaldu A. biennis menggunakan kromatografi turus Sepharose CL-6B. Berat molekul, komposisi monosakarida, ciri struktur, penyesuaian rantai dan harta termal EPS-1 ditentukan menggunakan kromatografi penapisan gel, kromatografi gas-spektroskopi jisim, spektroskopi infra merah Fourier-tertransformasi, ujian Congo merah dan analisis termogravimetrik. Aktiviti antioksidan in vitro dan pengaturan imuno EPS-1 masing-masing ditentukan menggunakan asai DPPH dan hidroksil radikal skaveng serta menganalisis pengeluaran NO dalam sel makrofaj RAW 264.7. Hasil kajian menunjukkan bahawa kultur media yang mengandungi $30 \mathrm{~g} / \mathrm{L}$ laktosa dan $3.0 \mathrm{~g} / \mathrm{L}$ tripton mempunyai sumber karbon dan nitrogen yang paling sesuai untuk pengeluaran EPS dalam A. biennis. Pengeluaran EPS maksimum $(18.29 \mathrm{~g} / \mathrm{L})$ diperoleh selepas penuaian selama 6 hari dalam reaktor tangki pengaduk 5L menggunakan kultur media yang paling sesuai. Selepas penulenan, EPS-1 dengan hasil sebanyak $85.4 \%$ dan kandungan karbohidrat sebanyak $96.1 \%$ telah diperoleh daripada kultur kaldu A. biennis. EPS-1 dicirikan sebagai heteropolisakarida neutral dengan berat molekul $22.07 \mathrm{kDa}$ dan terdiri daripada glukosa, mannosa dan galaktosa pada nisbah molar 3.3:2.0:1.0. EPS-1 dengan kestabilan termal yang agak tinggi wujud dalam konformasi gegelung rawak dalam media akuas dan mempunyai keupayaan radikal skaveng yang menonjol serta aktiviti rangsangan makrofaj in vitro. Oleh itu, EPS-1 boleh diterokai sebagai bahan berfungsi dengan potensi aplikasi dalam industri makanan, perubatan dan kosmetik.

Kata kunci: Abortiporus biennis; bioaktiviti; eksopolisakarida; fermentasi tenggelam; pencirian awal 


\section{INTRODUCTION}

Abortiporus biennis (Bull.) singer belongs to white rot Basidiomycetes and is mainly distributed in China, Japan and West Europe. This species is often parasitic on many types of broad-leaved trees or on the ground where wood was buried and thus causes white wood to decay. As a rare edible and medicinal mushroom, A. biennis has been used for hundreds of years due to its multiple pharmacological and biological activities (Zhang et al. 2011). Moreover, this organism is a fascinating producer of extracellular laccase and is viewed as an oxalate oxidase producing fungus (Jaszek et al. 2006), a unique feature among wood-degrading fungi (Grąz et al. 2009). Submerged fermentation is a feasible, simple and efficient method for extracellular laccase production (Ding et al. 2014; He et al. 2014; Jaszek et al. 2006). For example, He et al. (2014) had optimised the culture conditions of laccase productions in a submerged culture of $A$. biennis in a pilotscale bioreactor $(300 \mathrm{~L})$ using the rotating simplex method, and the maximum laccase production was $1361 \mathrm{U} / \mathrm{L}$ under the optimal culture medium. Exopolysaccharides (EPSs) as valuable metabolites have also been secreted in large quantities into the culture broth of $A$. biennis. Many studies reported that the EPSs harvested from fermentation broths of various fungi or mushrooms exhibit notable and excellent bioactivities, such as immunostimulatory, antitumor and antioxidant activities, and other pharmacological functions, thereby having great potential for applications in food, medicine and cosmetics (Cao et al. 2014; Chen et al. 2019; He et al. 2012; Meng et al. 2010). To the best of our knowledge, no or little information is available on the isolation, characterization and bioactivities of EPS produced from $A$. biennis in submerged fermentation.

In this study, the submerged culture conditions for the EPS production of A. biennis in shake-flasks and a $5 \mathrm{~L}$ stirred-tank reactor were investigated and screened. After isolation and purification, the physicochemical properties and preliminary structural characterizations of the purified EPS, namely EPS-1, were studied. The antioxidant and macrophage stimulation activities of the EPS-1 were also evaluated.

\section{MATERIALS AND METHODS}

\section{CHEMICALS}

Monosaccharide standards (arabinose, glucose, galactose, mannose, rhamnose and xylose), Congo red, glucuronic acid, trifluoroacetic acid, hydrogen peroxide $\left(\mathrm{H}_{2} \mathrm{O}_{2}\right)$ and 1,1-diphenyl-2-picrylhydrazyl (DPPH) were purchased from Sigma-Aldrich Chemical Co. (St. Louis, MO, USA). All other chemicals and solvents were of laboratory grade and used without further purification.

\section{MICROORGANISM, INOCULUM AND CULTURE CONDITIONS}

Microorganism of $A$. biennis was collected by our own laboratory and was used throughout the study. The stock culture was sustained by potato dextrose agar (PDA) slant and monthly subcultured at $25^{\circ} \mathrm{C}$ for 8 days and stored at $4^{\circ} \mathrm{C}$. The seed culture was grown in a $250 \mathrm{~mL}$ conical flask containing $50 \mathrm{~mL}$ of glucose-peptone (GP) medium (3\% glucose and $0.3 \%$ peptone, $\mathrm{pH} 6.5$ ) at $26^{\circ} \mathrm{C}$ for 4 days in a rotary shaker incubator at $150 \mathrm{rpm}$. A. biennis submerged cultures were conducted in $250 \mathrm{~mL}$ conical flasks with continuous stirring $(150 \mathrm{rpm})$, containing $50 \mathrm{~mL}$ media after inoculating with $4 \%(\mathrm{v} / \mathrm{v})$ of the seed culture. $A$. biennis was initially grown on PDA medium in a Petri dish and transferred into the seed medium by punching out 5 $\mathrm{mm}$ of the agar plate culture with a self designed cutter.

\section{CULTIVATION IN A 5-L STIRRED-TANK REACTOR}

A 5-L stirred-tank reactor with six-blade Rushton turbine impeller (Infors, Switzerland) was employed in this study for the batch submerged cultivation of $A$. biennis under the following conditions with inculation amount of $4 \%(\mathrm{v} / \mathrm{v})$, temperature at $26^{\circ} \mathrm{C}$, aeration rate of $2 \mathrm{vvm}$, agitation speed at $150 \mathrm{rev} / \mathrm{min}$, initial $\mathrm{pH}$ of 8.0 , and working volume of 3.0 L. Samples were collected at 1, 2, 4, 6 and 8 days, and subjected to direct observation of morphology using an image analyzer (DT2000 System, China) with software linked to a light microscope (Nikon, Japan) via a CCD camera.

MEASUREMENT OF THE YIELDS OF MYCELIA AND EPS

A. biennis mycelia were separated by filtration and washed thrice with double distilled water, dried in a vacuum oven at $70^{\circ} \mathrm{C}$ overnight to a constant weight, and the mycelia dry weight was determined gravimetrically. After filtration, the culture broths were collected and precipitated by addition of 4 volumes of $95 \%$ ethanol overnight, and then the crude EPS was obtained by centrifugation at $10,000 \mathrm{~g}$ for $15 \mathrm{~min}$. The EPS was redissolved in distilled water and the concentration of EPS was determined by the phenol-sulfuric acid method (Dubois et al. 1956).

\section{ISOLATION AND PURIFICATION OF EPS}

After a series of deproteinisation by Sevag method, dialysis and lyophilisation, the pretreated EPS was redissolved in $0.2 \mathrm{M} \mathrm{NaCl}$ buffer and loaded onto a pre-equilibrium Sepharose CL-6B column $(2.4 \mathrm{~cm} \times 100 \mathrm{~cm}$, Sigma Chemical Co. St. Louis, MO) and eluted with the same buffer at a flow rate of $0.6 \mathrm{~mL} / \mathrm{min}$ under room temperature. An automatic fraction collector was used to collect the eluate at a frequency of $5 \mathrm{~mL} /$ tube. Carbohydrates and proteins in each tube were monitored by the phenol-sulfuric acid method and the Bradford method at $490 \mathrm{~nm}$ and 280 nm, respectively (Bradford 1976; Dubois et al. 1956). The leading peak was collected, concentrated, dialysed and lyophilised to yield purified EPS, designated as EPS- 1 .

The total carbohydrate, uronic acid and protein contents of EPS-1 were determined by the phenol-sulfuric acid method using glucose as a standard (Dubois et al. 1956), via sulfuric acid-carbazole method using glucuronic 
acid as a standard (Bitter \& Muir 1962), and via the Bradford method using bovine serum albumin as a standard (Bradford 1976), respectively.

\section{PRELIMINARY STRUCTURAL CHARACTERISATIONS}

The gel-filtration chromatography on a Sepharose CL-6B column was applied to determine the molecular weight (MW) of EPS-1 according to our previous study (Cao et al. 2014). The calibration equation for average MW against retention time was prepared with Dextran MW standards ranging from $10 \mathrm{kDa}$ to $150 \mathrm{kDa}$ (Sigma-Aldrich Chemical Co., St. Louis, MO, USA). The experimental conditions were the same as described in Isolation and Purification of EPS section.

The monosaccharide composition of EPS-1 was analysed using gas chromatography-mass spectroscopy (GC-MS) on a Varian Star 3600 CX instrument (Varian Co., Lexington, MA, USA) with a fused silica capillary column (Na form, $30 \mathrm{~m} \times 0.25 \mathrm{~mm}$, Supelco Inc., Bellefonte, PA, USA) and a flame ionization detector with the conditions as reported before (Zheng et al. 2014).

Fourier-transform infrared (FT-IR) spectrum of EPS-1 was determined using a FT-IR spectrometer (Bruker Tensor 27 ) in the wave number range of $400-4000 \mathrm{~cm}^{-1}$ with $\mathrm{KBr}$ pellets and referenced against air.

Thermogravimetric analysis (TGA) of the EPS- 1 was carried out in a TA Q5000IR TGA apparatus. TGA curve plot was for the TGA signal (converted to percent weight change on the $Y$-axis) against the reference material temperature (on the $X$-axis).

The triple helix conformation or random coil structures of polysaccharide chains in an aqueous alkaline solution was investigated using Congo red test (Cao et al. 2014). Briefly, $5.0 \mathrm{mg}$ of EPS-1 was dissolved in 2.0 $\mathrm{mL}$ distilled water and mixed with an equal volume of 80 $\mu \mathrm{M}$ Congo red solution, together by drop-wise addition of $1 \mathrm{M} \mathrm{NaOH}$ solution to $0-0.5 \mathrm{M}$ final concentrations. UV-visible spectra of the resultant mixture at various concentration of the $\mathrm{NaOH}$ were scanned with the UVvisible spectrophotometer (TU-1800, China) at 400-800 $\mathrm{nm}$ and the maximum absorption wavelength $\left(\lambda_{\max }\right)$ was recorded.

\section{ANTIOXIDANT ACTIVITY ASSAYS}

Concerning the DPPH scavenging assay, the EPS-1 was previously dissolved in distilled water at various concentrations $(0-3.0 \mathrm{mg} / \mathrm{mL})$. A volume of $2 \mathrm{~mL}$ of the EPS-1 solution was mixed with an equal volume of 0.1 $\mathrm{g} / \mathrm{L}$ DPPH solution in $50 \%$ ethanol. The reaction mixture was stirred and incubated at $25^{\circ} \mathrm{C}$ for $20 \mathrm{~min}$ in the dark. The absorbance of the resulting solution was measured at $517 \mathrm{~nm}$ by using UV-2550 spectrophotometer (Shimadzu, Kyoto, Japan). The DPPH radical scavenging activity was calculated according to the following equation: scavenging activity $(\%)=\left[1-\left(\mathrm{A}_{1}-\mathrm{A}_{2}\right) / \mathrm{A}_{0}\right] \times 100 \%$, where $\mathrm{A}_{0}, \mathrm{~A}_{1}$ and $\mathrm{A}_{2}$ are the respective absorbance values of the blank control (distilled water), the EPS-1 with DPPH solution, and the EPS-1 with distilled water. Vitamin C $\left(\mathrm{V}_{\mathrm{c}}\right)$ was used as a positive antioxidant reference.

For the adapted hydroxyl radical $(\cdot \mathrm{OH})$ method, the EPS-1 was previously dissolved at various concentrations ( 0 to $3.0 \mathrm{mg} / \mathrm{mL}$ ) in distilled water. EPS-1 or control solution $(0.2 \mathrm{~mL})$ was added into an equal volume of an aqueous solution of $5 \mathrm{mM} \mathrm{FeSO}_{4}$. Then, $0.2 \mathrm{~mL}$ of $1 \%(\mathrm{v} / \mathrm{v}) \mathrm{H}_{2} \mathrm{O}_{2}$ was added into the mixture under continuous stirring. After stirring and incubation at $25^{\circ} \mathrm{C}$ for $60 \mathrm{~min}$, the absorbance of the resulting solution was measured at $510 \mathrm{~nm}$ using UV-2550 spectrophotometer (Shimadzu, Kyoto, Japan). The $\cdot \mathrm{OH}$ scavenging activity (\%) was estimated by the following formula: scavenging activity $(\%)=\left(1-\mathrm{A} / \mathrm{A}_{0}\right) \times 100 \%$, where $\mathrm{A}$, and $\mathrm{A}_{0}$ are the absorbance values of the sample and blank control (distilled water), respectively. $\mathrm{V}_{c}$ was used as a positive antioxidant reference.

\section{EFFECT OF EPS-1 ON NO PRODUCTION IN MACROPHAGE RAW 264.7 CELLS}

Mouse macrophage RAW264.7 cells were cultured in Dulbecco's modified Eagle (Gibco Co., Carlsbad, CA, USA) supplemented with $10 \%$ (w/v) fetal bovine serum, 100 units $/ \mathrm{mL}$ penicillin and $100 \mu \mathrm{g} / \mathrm{mL}$ streptomycin (Amersco Co., Solon, OH, USA) maintained at $37^{\circ} \mathrm{C}$ in an incubator with $5 \% \mathrm{CO}_{2}$ and a humidified atmosphere. The RAW264.7 cell suspension $\left(180 \mu \mathrm{L} ; 5 \times 10^{5}\right.$ cells $\left./ \mathrm{mL}\right)$ and the EPS-1 $(20 \mu \mathrm{L})$ at different concentrations $(100,200$, and $500 \mu \mathrm{g} / \mathrm{mL}$ ) were added to a $96-w e l l$ plate and incubated at $37^{\circ} \mathrm{C}$ in a $5 \% \mathrm{CO}_{2}$ atmosphere for $48 \mathrm{~h}$. The supernatants were collected, and NO production was determined by mixing with $50 \mu \mathrm{L}$ of Griess reagent ( $1 \%$ sulfanilamide, $0.1 \%$ naphthylethylenediamine dihydrochloride, and $2 \%$ phosphoric acid) for $10 \mathrm{~min}$ at $25^{\circ} \mathrm{C}$. NO production was measured by comparing the absorbance at $543 \mathrm{~nm}$ against a standard curve generated using $\mathrm{NaNO}_{2}$. PBS and lipopolysaccharide (LPS, $1 \mu \mathrm{g} / \mathrm{mL}$ ) were used as negative and positive controls, respectively.

\section{STATISTICAL ANALYSIS}

All experiments were conducted in three replicates and the mean \pm standard deviation (SD) was used in the analysis. The statistical analysis was performed by Student's $t$-test. Data Processing System (DPS Version 3.0) was used for the experimental designs and statistical differences were considered significant at $P<0.05$.

\section{RESULTS AND DISCUSSION}

\section{EFFECTS OF CARBON AND NITROGEN SOURCES FOR EPS PRODUCTION}

Different carbon and nitrogen sources were selected and kept at constant concentration levels of $30 \mathrm{~g} / \mathrm{L}$ and $3 \mathrm{~g} / \mathrm{L}$, respectively, for 8 days in the basal medium to screen for the most suitable carbon and nitrogen sources for EPS production in A. biennis (Figure 1). Among the 
carbon sources examined, the culture medium with $30 \mathrm{~g} / \mathrm{L}$ lactose could produce the highest yields of biomass $(1.47$ $\mathrm{g} / \mathrm{L}$ ) and EPS (14.44 g/L) (Figure 1(A)). In addition, the EPS production was almost close to 0 in the presence of sorbitol as the carbon source in the culture medium. This result indicated that sorbitol can inhibit the EPS synthetic pathway, which was in agreement with our previous study (Zheng et al. 2014). Hence, we viewed lactose as the best carbon source for the EPS production in A. biennis. This finding was opposite to the results for the carbon source requirements reported by other researchers in different fungi or mushrooms (Chen et al. 2019; Meng et al. 2010). Figure 1(B) shows that among the six different nitrogen sources, organic nitrogen sources produced the relatively highest mycelial growth and EPS production in A. biennis. Notably, the maximum production of EPS $(8.07 \mathrm{~g} / \mathrm{L})$ was obtained when tryptone was used as nitrogen source, and the yield of biomass was $1.13 \mathrm{~g} / \mathrm{L}$, which was lower than that in medium containing yeast extract $(3.73 \mathrm{~g} / \mathrm{L})$. Considering that the EPS production was established in the current work, we then selected lactose and tryptone as the best carbon and nitrogen sources for A biennis submerged fermentation.

\section{EPS PRODUCTION IN A 5 L STIRRED-TANK REACTOR}

Figure 2 presents the typical time profile of EPS production by $A$. biennis in a $5 \mathrm{~L}$ stirred-tank reactor under the most suitable culture conditions (lactose $30 \mathrm{~g} / \mathrm{L}$, tryptone 3 $\mathrm{g} / \mathrm{L}, 26^{\circ} \mathrm{C}$ and $\mathrm{pH} 8.0$ ). The EPS production reached a maximum concentration of $18.29 \mathrm{~g} / \mathrm{L}$ at day 6 , which was considerably higher than that in shake-flask cultures (14.44 g/L, Figure 1(A)). This phenomenon occurred because the high shear force provided by stirred-tank reactor could improve the mass transfer, thus maintaining a satisfactory supply of sugars and other nutrients to the cells, accelerating the EPS anabolic synthesis, and contributing to the enhanced EPS production in the submerged fermentation of A. biennis (Fontana et al. 2009). Figure 3 displays the typical morphology changes during the entire submerged cultivation period in the stirred-tank reactor. Fresh cell showed a fungus pellet with a number of fluffy hairiness, which was a complex of EPS and mycelium that existed in and around the fungal pellet core region. In the submerged cultures, the fungal pellets became clear, and the outer hairy region of the fungal pellets thinned out. These phenomena occurred because the high shear force in the stirred-tank
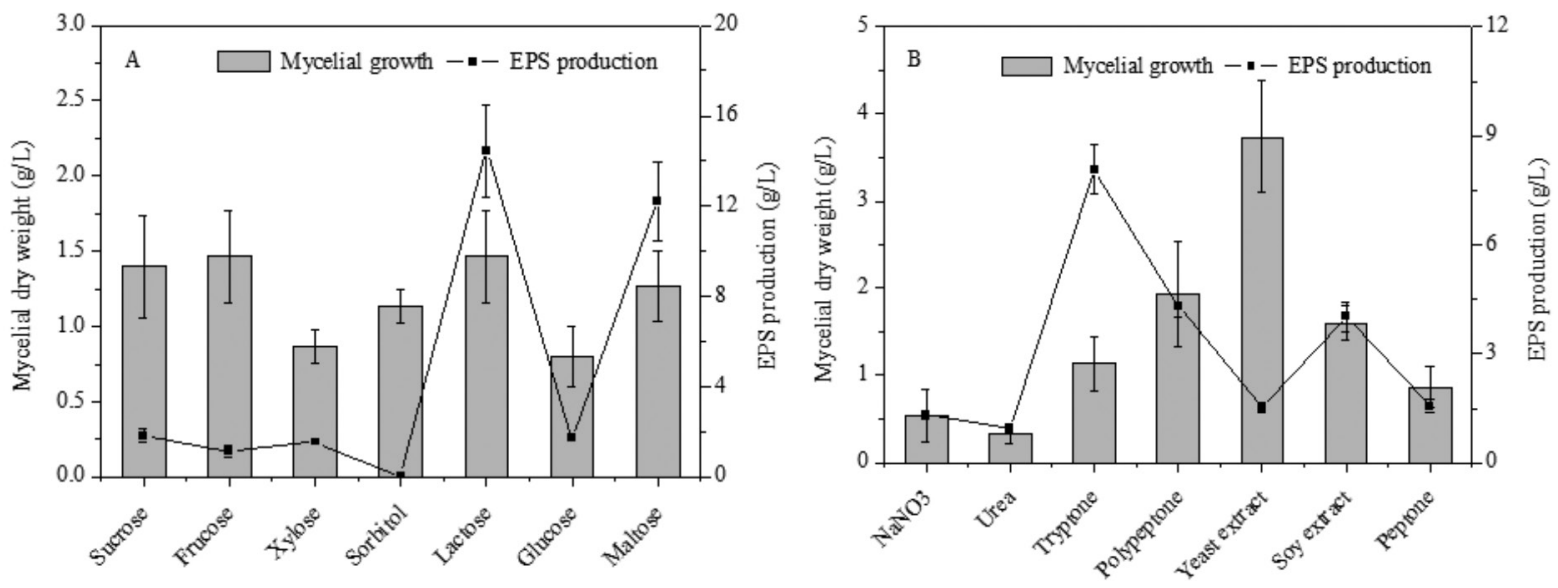

FIGURE 1. Effect of (A) carbon and (B) nitrogen on mycelia growth and EPS production by A. biennis in shake flask cultures. Each value is expressed as a mean \pm standard deviation $(\mathrm{SD}, n=3)$

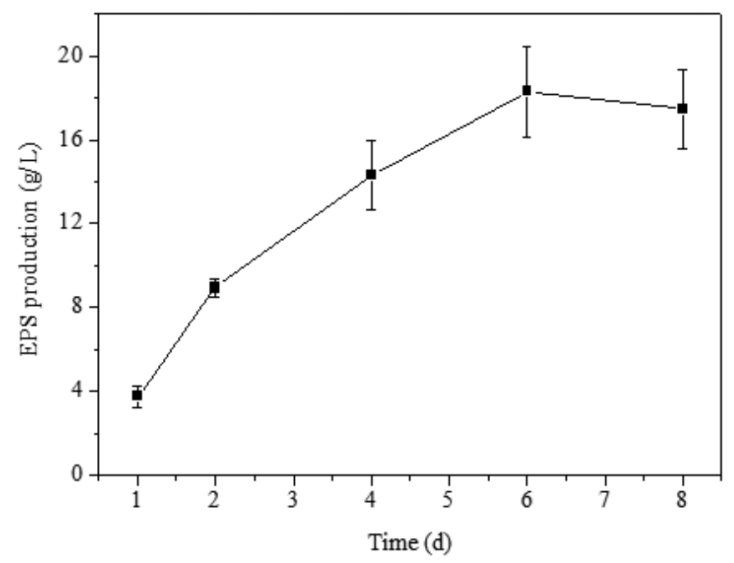

FIGURE 2. Time profile of EPS in submerged culture of A. biennis in a stirred-tank reactor 

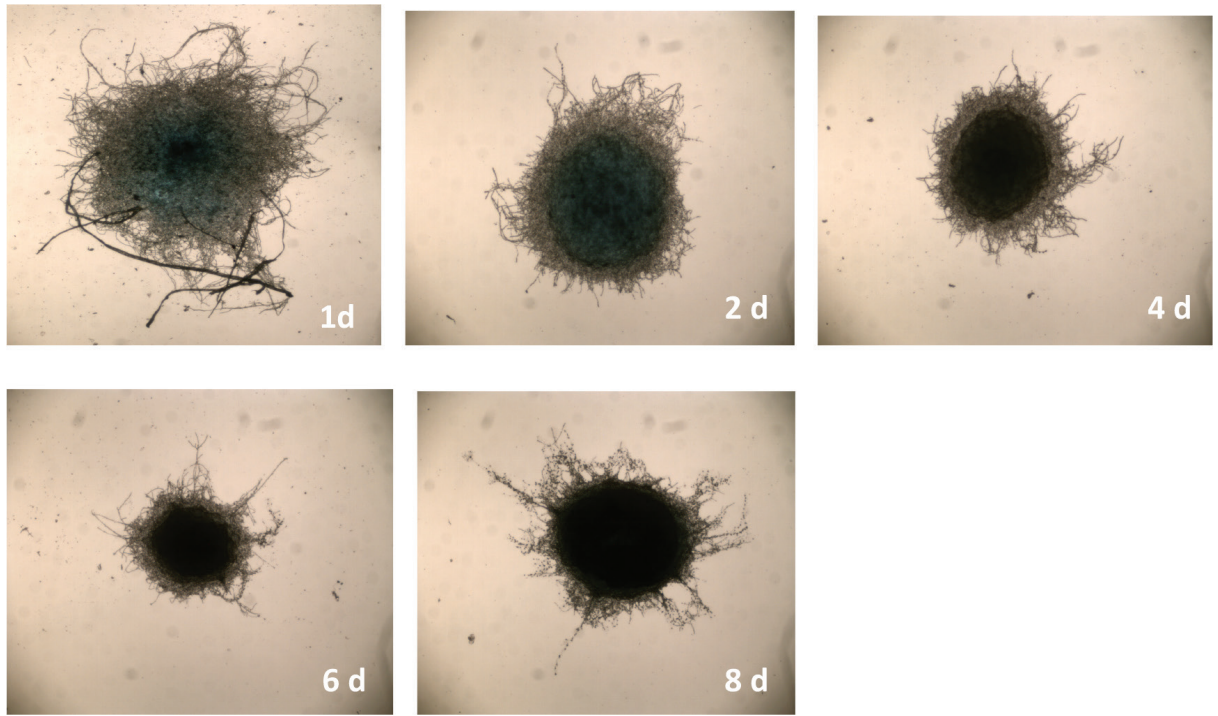

FIGURE 3. The morphological changes in A. biennis in a 5-L stirred-tank reactor. All representative images were taken at 4-fold magnification, at 1,2, 4, 6 and $8 \mathrm{~d}$ mean cultivation period in day

reactor could easily destroy the hairiness of the fungal pellet and consequently lower the EPS production after 8 days of cultivation.

\section{PURIFICATION AND PRELIMINARY STRUCTURAL CHARACTERISATIONS OF EPS-1}

In this work, the crude EPS harvested from the culture broth of $A$. biennis was purified by Sepharose CL-6B column chromatography to obtain a purified polysaccharide (Figure 4(A)), designated as EPS-1, with a yield of $85.4 \%$. In Figure 4(A), the elution peak showed only one absorbance at $490 \mathrm{~nm}$ but not at $280 \mathrm{~nm}$, indicating that the EPS-1 is a polysaccharide. The carbohydrate content of EPS-1 was $96.1 \%$, and no protein or uronic acid was present in EPS-1. This result suggested that EPS-1 is a neutral polysaccharide. Moreover, no characteristic absorption peaks at 250 and $280 \mathrm{~nm}$ were observed in the UV-visible absorption spectrum of EPS-1 (data not shown), thus confirming the absence of nucleic acids and proteins in EPS-1. This result was consistent with those in Figure 4(A). Gel-filtration chromatography on Sepharose CL-6B column was applied to determine the MW of the EPS-1 (Figure 4(B)). The MW of EPS-1 was $22.07 \mathrm{kDa}$ according to the calibration equation derived from the linear regression of the calibration curve with standard dextrans (Figure 4(B)). Based on the monosaccharide composition analysis, EPS-1 is a heteropolysaccharide mainly composed of glucose, mannose and galactose in a molar ratio of 3.3:2.0:1.0. Collectively, these results indicated that EPS- 1 is a neutral heteropolysaccharide.

Figure 5(A) displays the FT-IR spectrum of EPS-1. Two characteristic absorption peaks of polysaccharides were observed, a strong and broad absorption peak at $3324.5 \mathrm{~cm}^{-1}$ corresponding to the $\mathrm{O}-\mathrm{H}$ stretching vibration and a weak
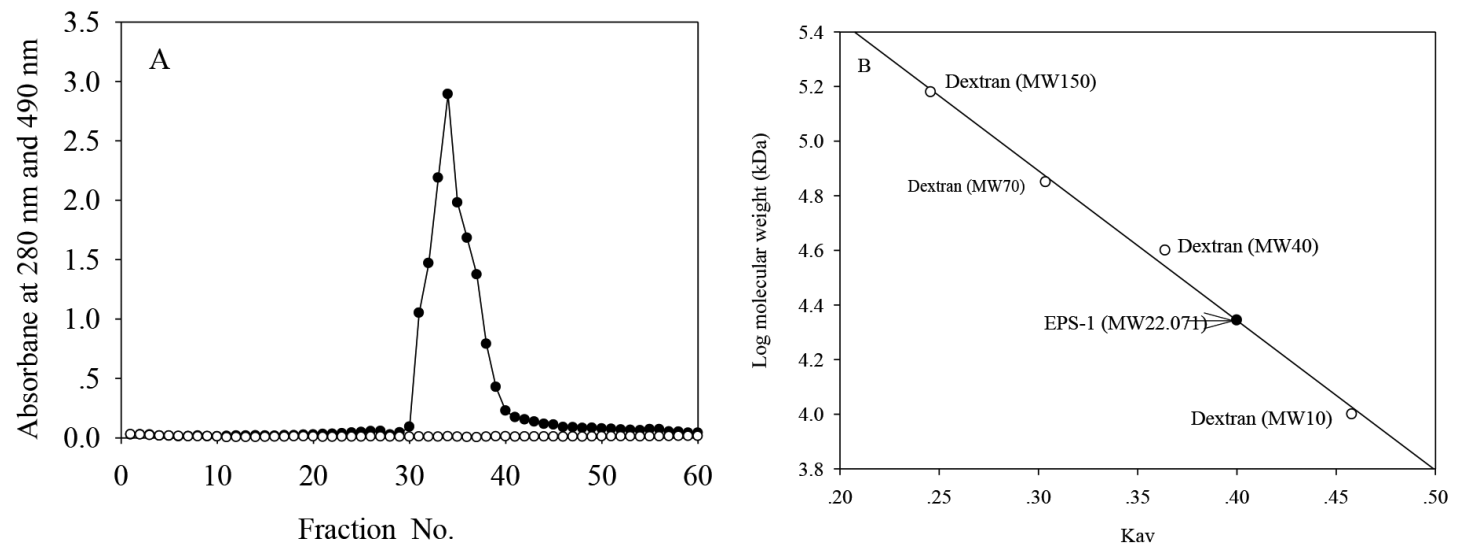

FIGURE 4. (A) Elution profile of the EPS-1 from A. biennis in Sepharose CL-6B column chromatography. Elutes were analysed by measuring the absorbance at $490 \mathrm{~nm}$ for carbohydrate (black circle) and the absorbance at $280 \mathrm{~nm}$ for protein (blank circle). (B) Determination of molecular weight of EPS-1 in Sepharose CL-6B column chromatography. $\mathrm{K}_{\mathrm{av}}=\left(\mathrm{V}_{\mathrm{e}}-\mathrm{V}_{\mathrm{o}}\right) /\left(\mathrm{V}_{\mathrm{t}}-\mathrm{V}_{\mathrm{o}}\right)\left(\mathrm{V}_{\mathrm{o}}\right.$; void volume, $\mathrm{V}_{\mathrm{t}}$; total volume, $\mathrm{V}_{\mathrm{e}}$; elution volume). EPS-1 was denoted as a closed circle. 

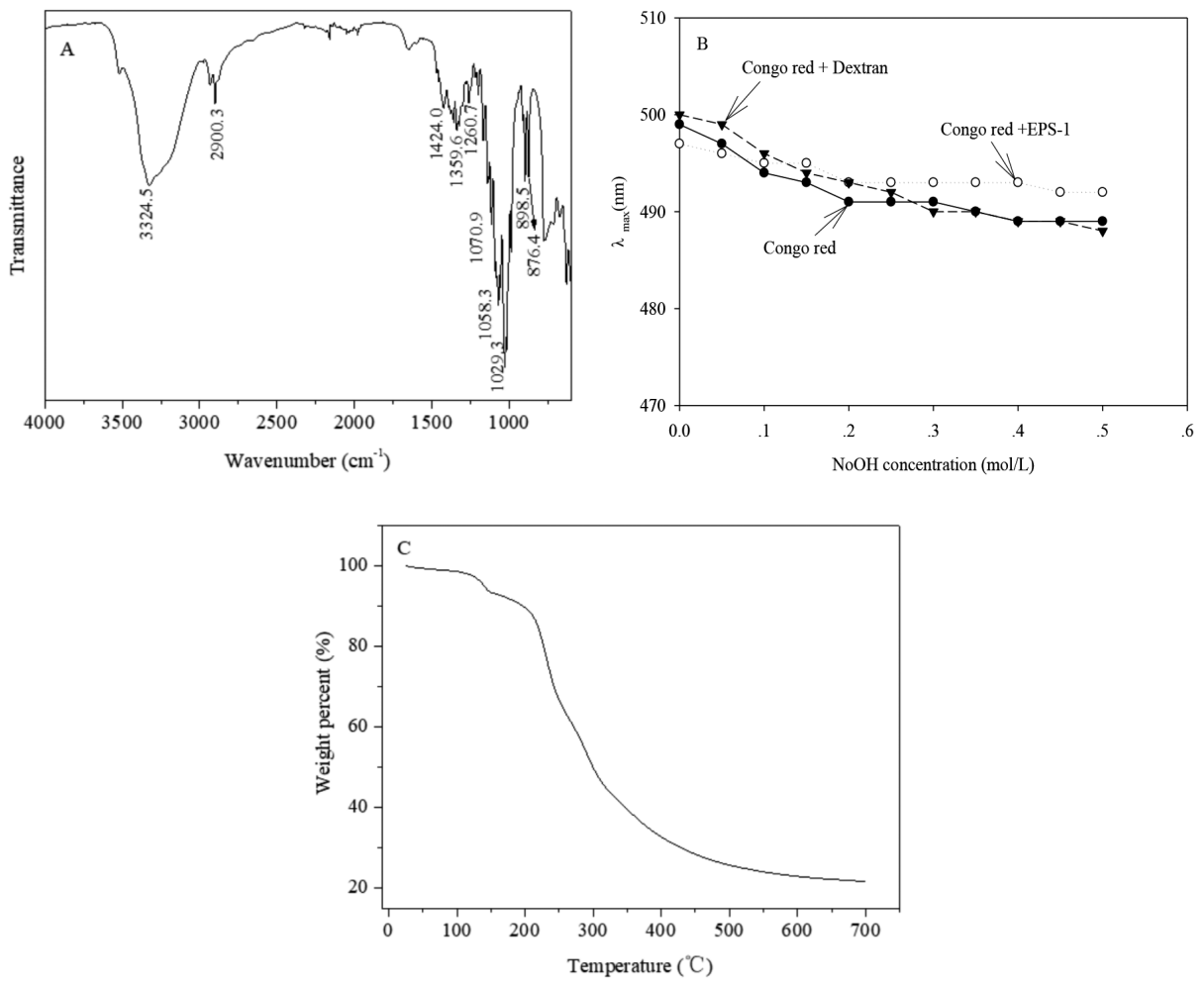

FIGURE 5. (A) FT-IR spectrum of EPS-1. (B) TGA thermogram of EPS-1. (C) Helix-coil transition analysis of EPS- 1 based on the maximum absorption wavelength of the Congo red-EPS- 1 complex at various concentrations of $\mathrm{NaOH}$. Congo red and dextran viewed as controls

absorption peak at $2900.3 \mathrm{~cm}^{-1}$ due to the $\mathrm{C}-\mathrm{H}$ stretching vibration. No absorption peak was observed at $1730 \mathrm{~cm}^{-1}$, which suggested the absence of uronic acid in the EPS-1 structure (Jing et al. 2014). The absorption band at 1652.7 $\mathrm{cm}^{-1}$ was due to the bound water. Strong absorption bands in the range of $1000-1200 \mathrm{~cm}^{-1}$ were associated with the stretching vibrations of C-O-C and C-O-H groups (Zhang 1999). Three stretching peaks at $1070.9,1058.3$ and 1029.3 $\mathrm{cm}^{-1}$ further showed the presence of pyranoside in EPS-1. In addition, characteristic peaks at 876.4 and $898.5 \mathrm{~cm}^{-1}$ suggested that $\alpha$-and $\beta$-anomeric configurations existed in EPS-1 structure.

Figure 5(B) shows the changes in the maximum absorbance $\left(\lambda_{\max }\right)$ of Congo red-EPS-1 solution with $\mathrm{NaOH}$ concentration ranging from $0 \mathrm{M}$ to $0.5 \mathrm{M}$ in comparison with dextran, a known random coil conformer. Congo red-EPS- 1 and -dextran solutions did not change the $\lambda_{\max }$ between 500 and $490 \mathrm{~nm}$ compared with that of Congo red alone within the $0-0.5 \mathrm{M} \mathrm{NaOH}$ concentration range, suggesting that similar to dextran, the EPS- 1 chain exhibits a random coil conformation instead of a helix structure in the aqueous medium.

Figure 5(C) shows the TGA curve of EPS-1. The degradation temperature $\left(\mathrm{T}_{\mathrm{d}}\right)$ of EPS- 1 was $115^{\circ} \mathrm{C}$, which suggested that the thermogravimetric stability of EPS-1 was decomposed at temperatures above the observed $\mathrm{T}_{\mathrm{d}}$. Furthermore, we noted a significant mass loss in EPS-1 at $250^{\circ} \mathrm{C}$, and this mass loss gradually decreased to leave a final residue of $c a .21 .61 \%$ of the original EPS-1 mass.
Thus, the TGA analysis in this work confirmed that the EPS-1 possesses a relatively high thermal stability.

\section{In vitro ANTIOXIDANT ACTIVITY}

The EPS derived from fungi or mushrooms as excellent free radical scavengers exerted important roles in the prevention of oxidative stress in living organism, thereby having great potential as natural antioxidants. In this study, free radical-scavenging abilities on DPPH and - $\mathrm{OH}$ were adopted to evaluate the in vitro antioxidant activities of EPS- 1 and compare them with those of the positive control, Vc. As shown in Figure 6(A)-6(B), EPS exhibited strong DPPH and $\cdot \mathrm{OH}$ radical-scavenging abilities in dose-dependent manners at $0-3.0 \mathrm{mg} / \mathrm{mL}$. At $3.0 \mathrm{mg} / \mathrm{mL}$, the DPPH and $\cdot \mathrm{OH}$ radical-scavenging abilities of EPS- 1 were $70.78 \%$ and $64.55 \%$, respectively, which were weaker than those of $\mathrm{Vc}(90.59 \%$ and $72.58 \%$, respectively, $0.5 \mathrm{mg} / \mathrm{mL}$ ). Its noticeable antioxidant activities might be related to carbohydrate content, monosaccharide composition, MW, chemical structure and chain conformation. In particular, the MW of EPS-1 plays an important role in its antioxidant activity, and a relatively low MW appears to increase the radicalscavenging ability. For example, Xing et al. (2005) have confirmed that these free radical-scavenging capacities for low MW polysaccharides were more pronounced than those for high MW polysaccharides, because low MW polysaccharides have many reductive $-\mathrm{OH}$ terminals that 

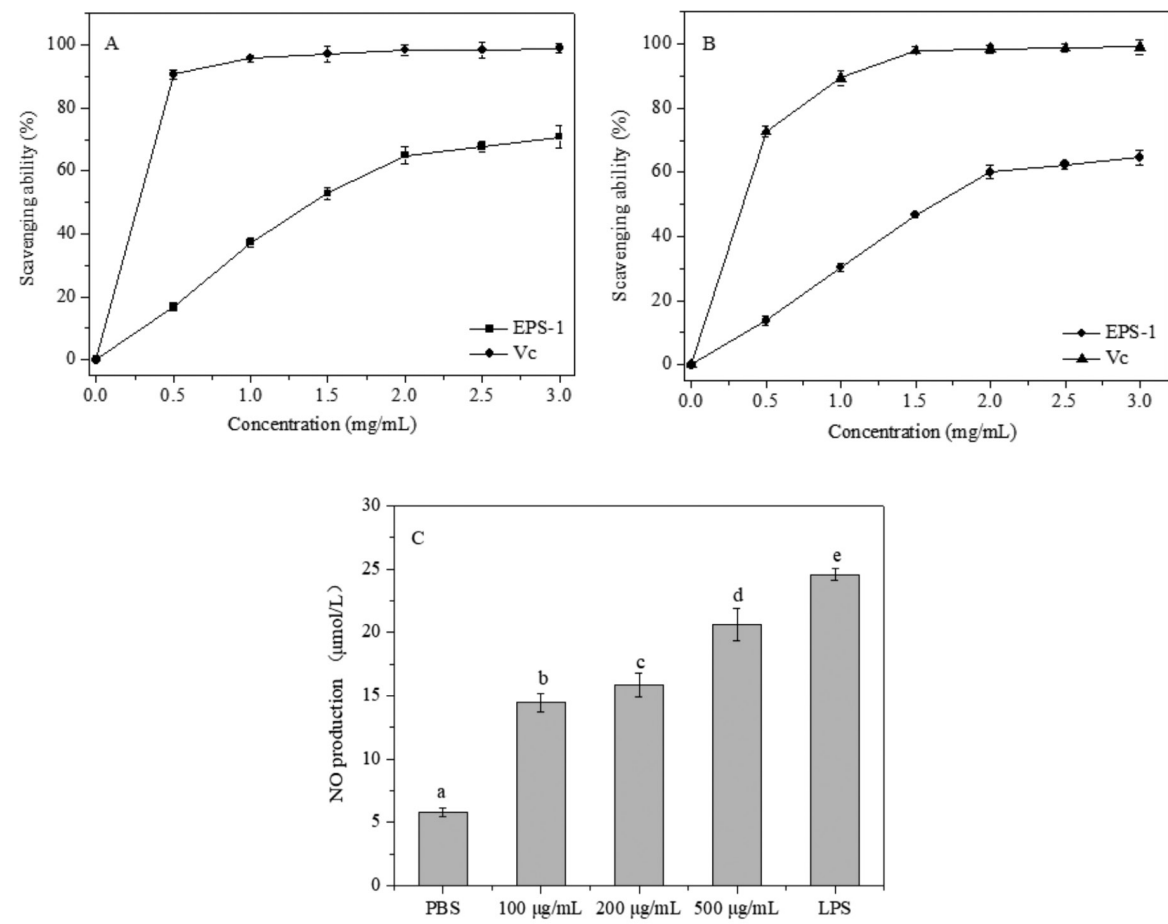

FIGURE 6. Antioxidant activities in vitro of EPS-1 in terms of its scavenging abilities on (A) scavenging abilities on DPPH and (B) ·OH. (C) Effect of EPS-1 on NO production in RAW 264.7 cells. RAW 264.7 cells were treated with various concentrations of EPS-1, or LPS $(1 \mu \mathrm{g} / \mathrm{mL})$ for $48 \mathrm{~h}$. Each value is presented as mean $\pm \mathrm{SD}(\mathrm{n}=3)$. Bars with different letters are statistically different $(P<0.05)$

can react with radical series. In summary, these results indicated that EPS-1 with high carbohydrate content $(96.1 \%)$ and low MW $(22.07 \mathrm{kDa})$ exhibits potential antioxidant capacities.

\section{EFFECT OF EPS-1 ON NO PRODUCTION IN MACROPHAGE RAW 264.7 CELLS}

In immunopharmacology, NO as key molecule exhibits beneficial biological effects on various normal cells that are mostly connected with immunomodulatory or inflammatory or physiological processes (Nathan 1992). As an important cytotoxic mediator, this molecule is conducive to the antimicrobial and tumoricidal activities of the macrophages and plays a vital role in the pathogenesis of several infectious and inflammatory diseases (Bogdan 2001; Nathan 1992). Figure 6 presents the effect of EPS-1 on NO production in macrophage RAW 264.7 cells. The NO production of RAW 264.7 cells was increased after the incubation of different concentrations of EPS-1 in a dose-dependent fashion. In comparison, the NO generation at the measured concentration range was significantly higher than that of the negative control $(P<0.05)$. This finding indicated that EPS- 1 can stimulate the release of NO by macrophage RAW 264.7 cells, thus showing its underlying immune function. Similar results were confirmed by Hu et al. (2013), who found that the levels of NO produced by macrophages were increased by high polysaccharide concentration. At $500 \mu \mathrm{g} / \mathrm{mL}$, the NO secretion of EPS-1 was $24.56 \mu \mathrm{mol} / \mathrm{L}$, which was nearly close to that of the LPS group $(24.56 \mu \mathrm{mol} / \mathrm{L}, 1 \mu \mathrm{g} / \mathrm{mL})$. The prominent NO stimulating activity of EPS- 1 might be due to its high carbohydrate content and low MW.

\section{CONCLUSION}

In this study, we investigated the production, physicochemical characterization and biological activities of EPS from the submerged culture of A. biennis. Lactose $(30 \mathrm{~g} / \mathrm{L})$ and tryptone $(3 \mathrm{~g} / \mathrm{L})$ were identified as the best carbon and nitrogen sources, respectively, for EPS production in A. biennis submerged fermentation. The maximum EPS production achieved was $18.29 \mathrm{~g} / \mathrm{L}$ at day 6 in a 5 L stirred-tank reactor under the most suitable culture conditions. After purification using gel-filtration chromatography, EPS- 1 with $85.4 \%$ yield and $96.1 \%$ carbohydrate content was obtained from the crude EPS, which was harvested from the culture broths of A. biennis. EPS-1 is a neutral heteropolysaccharide mainly composed of glucose, mannose and galactose at a molar ratio of 3.3:2.0:1.0 and has a MW of 22.07 kDa. EPS-1 with a relatively high thermal stability existed as a random coil conformation in the aqueous medium, and exhibited noticeable radical-scavenging ability and NO stimulating activity in macrophage RAW 264.7 cells. Further investigations on its bioactivity in vivo and detailed structural characterization are currently underway in our laboratory. 


\section{ACKNOWLEDGEMENTS}

This work was supported by the National Science Foundation of China (U1604176) and Program for Innovative Research Team (in Science and Technology) in University of Henan Province (Grant No 20IRTSTHN022).

\section{REFERENCES}

Bradford, M. 1976. A rapid and sensitive method for the quantitation of microgram quantities of protein utilizing the principle of protein-dye binding. Analytical biochemistry 72: $248-254$

Bitter, T. \& Muir, H.M. 1962. A modified uronic acid carbazole reaction. Analytical Biochemistry 4(4): 330-334.

Bogdan, C. 2001. Nitric oxide and the immune response. Nature Immunology 2: 907-916.

Cao, J., Zhang, H.J. \& Xu, C.P. 2014. Culture characterization of exopolysaccharides with antioxidant activity produced by Pycnoporus sanguineus in stirred-tank and airlift reactors. Journal of the Taiwan Institute of Chemical Engineers 45: 2075-2080.

Chen, L., Wang, Z., Zhang, B., Ge, M., Ng, H., Niu, Y. \& Liu, L. 2019. Production, structure and morphology of exopolysaccharides yielded by submerged fermentation of Antrodia cinnamomea. Carbohydrate Polymers 205: 271278.

Ding, Z., Chen, Y., Xu, Z., Peng, L., Xu, G., Gu, Z., Zhang, L., Shi, G. \& Zhang, K. 2014. Production and characterization of laccase from Pleurotus ferulae in submerged fermentation. Annals of Microbiology 64(1): 121-129.

Dubois, M., Gilles, K.A., Hamilton, J.K., Rebers, P.A. \& Smith, F. 1956. Calorimetric method for determination of sugars and related substances. Analytical Chemistry 28(3): 350-366.

Fontana, R.C., Polidoro, T.A.\& Silveira, M.M. 2009. Comparison od stirred tank and airlift bioreactors in the production of polygalacturonases by Aspergillus oryzae. Bioresoure Technology 100(19): 4493-4498.

Grąz, M., Jarosz-Wilkolazka, A. \& Pawlikowska-Pawlęga, B. 2009. Abortiporus biennis tolerance to insoluble metal oxides: Oxalate secretion, oxalate oxidase activtiy, and myceilal morphology. Biometals 22: 401-410.

He, P.X., Pan, L.G., He, X.S. \& Xu, C.P. 2014. Optimization of culture conditions for laccase production from Abortiporus biennis in a pilot-scale bioreactor. Archives of Biological Sciencens Belgrade 66(4): 1567-1574.

He, P., Geng, L., Wang, Z., Mao, D., Wang, J. \& Xu, C. 2012. Fermentation optimization, characterization and bioactivtiy of exopolysaccharides from Funalia trogii. Carbohydrate Polymers 89(1): 17-23.

Hu, Q.M., Mei, Y.X. \& Liang, Y.X. 2013. Immune activties of polysaccharides isolated in vitro purified from Phellinus linteus. Food Science and Technology 38: 142-145.

Jaszek, M., Grzywnowicz, K., Malarczyk, E. \& Leonowicz, A. 2006. Enhanced extracellular laccase activity as a part of the system of white rot fungi: Trametes versicolor and Abortiporus biennis to paraquat-caused oxidative stress conditions. Pesticide Biochemistry and Physiology 85(3): 147-154.
Jing, Y., Cui, X., Chen, Z., Huang, L., Song, L., Liu, T., Lv, W. \& Yu, R. 2014. Elucidation and biological activties of a new polysaccharide from cultured Cordyceps militaris. Carbohydrate Polymers 102: 288-296.

Meng, F., Liu, X., Jia, L., Song, Z., Deng, P. \& Fan, K. 2010. Optimization for the production of exopolysaccharides from Morchella esculenta SO-02 in submerged culture and its antixodiant activties in vitro. Carbohydrate Polymers 79(3): 700-704.

Nathan, C. 1992. Nitric oxide as a secretory product of mammalian cells. The Journal of the Federation of American Societies for Experimental Biology 6(12): 3051-3064.

Xing, R.G., Liu, S., Guo, Z.Y. \& Yu, H.H. 2005. Relevance of molecular weight of chitosan and its derivatives and their antixodiant activties in vitro. Bioorganic and Medicinal Chemistry 13(5): 1573-1577.

Zhang, W.J. 1999. Biochemical Techniques in Complex Carbohydrates. 2nd ed. Hangzhou: Zhejiang University Press.

Zhang, G.Q., Tian, T., Liu, Y.P., Wang, H.X. \& Chen, Q.J. 2011. A laccase with anti-proliferative activtiy against tumor cells from a white root fungus Abortiporus biennis. Process Biochemistry 46(12): 2336-2340.

Zheng, J.Q., Mao, X.J., Geng, L.J., Yang, G.M. \& Xu, C.P. 2014 Production optimization, preliminary characterization and bioactivtiy of exopolysaccharides from Incutis tamaricis (Pat.) Fiasson \& Niemela. Journal of the Taiwan Institute of Chemical Engineerings 45: 725-733.

Zhangde Long, Hong Liu, Jigang Li, Jiansheng Sun, Yun Xue, Zhizhong $\mathrm{Hu} \& \mathrm{Zan} \mathrm{Su}$

Technical Center of China Tobacco Guangxi Industrial Co. Ltd Nanning, Guangxi, 530001

China

Chunping $\mathrm{Xu}$

College of Food and Biology Engineering

Zhengzhou University of Light Industry

Zhengzhou, 450016

China

Jing-Kun Yan*

School of Food \& Biological Engineering

Jiangsu University

Zhenjiang, 212013

China

*Corresponding author; email: jkyan_27@163.com

Received: 23 December 2018

Accepted: 8 October 2019 